\title{
OPTIMIZATION OF SUPPLY CHAIN WITH \\ UNCERTAINTIES
}

\section{PIEDĀVĀJUMA ĶĒDES OPTIMIZĀCIJA AR MAINĪGAJIEM \\ Hayk KHACHATRYAN}

PhD student

\section{Nora MKRTCHYAN}

PhD student

\author{
Aram ARAKELYAN \\ Prof., Dr. \\ Department of Mathematical Modeling in Economics, Yerevan State University \\ E-mail: hayk_kh@yahoo.co.uk \\ Yerevan, Armenia
}

\begin{abstract}
The purpose of this study is to clarify the approach by which companies are solving the problems of optimization of Supply Chain with uncertainties through application of operations research and numerical methods. The problem of Supply Chain maximization is considered on a global scale and the model with uncertainties is developed. An algorithm for optimization is presented for this model.
\end{abstract}

Keywords: Supply, Chain, Optimization, Management, Uncertainty, Operation, Research, Model, Algorithm.

\section{Introduction}

In recent years management problems of Supply Chain (SC) have generated important questions concerning uncertainty and needs to optimize the process of management in various economic sectors. Thus the focus of organizations involved in SC is targeted to the maximization of own profit. Consequently, to reach this goal they try to manage input and output resources.

For this reason, problems between the seller and the buyer raising and depending from the number of organizations appearing as SC members constitute basic blocks of any simple or complex SC.

Nowadays, SC management problems under complete information are intensively studied in various papers. As one of effective mechanisms of the coordination of SC, a quantity discount is considered by Munson and Rosenblatt (1998). An application of fuzzy set theory for supply chain coordination is considered and a coordination mechanism through quantity discount policy under asymmetric information environment is designed by C.Yang and M.Wee (2001).

The literature devoted to SC coordination allows distinguishing the following three classes. The class concerning to buyer's perspective 
model considers the problem of buyer's requirements optimization with the assumption that sellers have complete information on the buyer's cost structure.

The next class is concerned to the seller's perspective model when pricing scheme "is profitable to the seller as long as the discount offered to the buyer(s) is less than the seller's cost saving".

Among SC model the class of joint buyer - seller models takes up a considerable amount of research. This class of models considers quantity discount strategies maximizing the system profit.

In all these cases the exact parameter value is not known and the decision maker is facing uncertainty. At absence of perfect information, the decision maker may not be able to know consequences of a particular choice he made. Thus, better is the information reducing of uncertainty to be available and consequently it leads to better decisions providing increased profit of the system.

Therefore, the study of relationship between uncertainty and information acquisition allows bridging the gap in the SC literature by proposing total cost consisting of two types of costs: uncertain cost and certain cost (Santanu Sinha, S.P. Sarmah (2008)). Several assumptions are necessary to provide straightforward analytical results. First, the supplier and the factories as members of SC are completely endowed with two factors of production: labor and capital. These two actors are used for the following production activities: first, both factors are used to produce the homogeneous final good (raw materials from customers).

During last two decades the Supply Chain Management (SCM) became hot debated topic both in academy and industry. The research was focused on the global as well local optimization. According to [2,3], previous models could be divided into the following 4 types: integrated seller - buyer (IVB) models, integrated procurement - production (IPP) system and MAD manufacturing, assembly and distribution integration).

Approach of the supply chain maximization with uncertainty targeted to coordination is presented in [4].

Integrated Supply Chain with multiple manufacturers, multiple suppliers, multiple distributors and multiple customers is considered in [2]. Concerning the products it's assumed that demands of the products are to be fuzzy and shortage cost is considered. Contrary to [2], demands of the products are assumed to be contingent in the present paper. The approach for optimization based on the model [2] is considered. The system of equations (nonlinear) is given and the approach for the solution based on [1] is presented. 


\section{Definitions and notations}

General definitions and used notations of the model are the following. The SC consists of the set of multiple:

a) Suppliers $\{1,2, \ldots, n, \ldots, N\}$,

b) Raw materials $\{1,2, \ldots, r, \ldots, R\}$,

c) Factories $\{1,2, \ldots, j, \ldots, J\}$,

d) Distribution centers (DC) $\{1,2, \ldots, z, \ldots, Z\}$,

e) Set of products $\{1,2, \ldots, i, \ldots, I\}$,

f) Customers $\{1,2, \ldots, m, \ldots, M\}$.

Let us denote

Let us denote as labor

$w_{n}^{1}\left(u_{n}^{1}\right)$-cost of capital (labor) of the $n$-th supplier of raw materials, $n=1,2, \ldots, n, \ldots, N$.

$w^{2}{ }_{j}\left(u^{2}{ }_{j}\right)$-cost of capital (labor) of the $j$-th factory, $j=1,2, \ldots, j, \ldots, J$.

$w_{z}^{3}\left(u_{z}^{3}\right)$-cost of capital (labor) of the $z$-th Distribution Center, $z=1,2, \ldots, z, \ldots, Z$.

$w^{4}{ }_{m}\left(u^{4}{ }_{m}\right)$-cost of capital (labor) of the $m$-th Distribution Center, $m=1,2, \ldots, m, \ldots, M$.

$K_{n}\left(L_{n}\right)$-capital (labor) of the $n$-th supplier of raw materials, $n=1,2, \ldots, n, \ldots, N$.

$K_{j}\left(L_{j}\right)$-capital (labor) of the $j$-th factory, $j=1,2, \ldots, j, \ldots, J$.

$K_{z}\left(L_{z}\right)$-capital (labor) of the $z$-th Distribution Center, $z=1,2, \ldots, z, \ldots, Z$.

$K_{m}\left(L_{m}\right)$-capital (labor) of the $m$-th Distribution Center, $m=1,2, \ldots, m, \ldots, M$.

$t_{r, n}$-unit production cost of $n$-th supplier of raw materials, supplying raw material $r, r=1,2, \ldots, r, \ldots R, n=1,2, \ldots, n, \ldots, N$.

$q_{i, j}$-unit manufacturing cost of $i$-th product produced in the $j$-th factory $i, i=1,2, \ldots, i, \ldots I, j=1,2, \ldots, j, \ldots, J$.

$f_{r, n}$-unit shipping cost of $r$-th raw materials supplied from $n$-th supplier.

$p_{i, j}$-unit shipping cost of $i$-th product supplied from $j$-th factory.

$c_{i, z}$-unit shipping cost of $i$-th product supplied from $z$-th Distribution Center.

$e_{i, z}$-unit retail cost of $i$-th product supplied from $z$-th Distribution Center.

$H_{r, n}$-quantity (price) of $r$-th raw materials supplied from $n$-th supplier. 
$Q_{i, j}$-quantity (price) of $i$-th product supplied from $j$-th factory.

$C_{i, z}$-quantity (price) of $i$-th product supplied from $z$-th Distribution Center.

$E_{i, z}$-quantity (retail price) of $i$-th product supplied from $z$-th Distribution Center.

$\gamma_{i, j, r, n}$-portion of $r$-th raw materials supplied from $n$-th supplier for the production of $i$-th product in $j$-th factory.

$\delta_{i, z, m}$ - portion of $i$-th product supplied to $z$-th Distribution Center for $m$-th customer.

$\varsigma_{i, z m}-$ retail portion of $i$-th product supplied to $z$-th Distribution Center for $m$-th customer.

$\chi_{r}$ - portion of capital of $n$-th raw materials supplier to produce $r-$ th raw materials.

$v_{r}$ - portion of labor of $n$-th raw materials supplier to produce $r$-th raw materials.

$$
G_{R, n}\left(K_{n}, L_{n}\right)
$$

production function of $n$-th raw materials supplier.

$$
G_{F, j}\left(K_{j}, L_{j}\right)
$$

production function of $j$-th factory.

$$
G_{z, z}\left(K_{z}, L_{z}\right)
$$

production function of $z$-th Distribution Center.

$$
G_{M, m}\left(K_{m}, L_{m}\right)
$$

production function of for $m$-th customer.

Consequently, if assume that

$$
\begin{gathered}
G_{R, n}\left(\chi_{r} K_{n}, v_{r} L_{n}\right)=H_{r, n} \text { than } \\
t_{r, n}=\frac{w_{n}^{1} \chi_{r} K_{n}+u_{n}^{1} v_{r} L_{n}}{G_{R, n}\left(\chi_{r} K_{n}, v_{r} L_{n}\right)}
\end{gathered}
$$

is unit shipping cost of $r$-th raw materials supplied from $n$-th supplier.

$$
\psi_{i, j}=\sum_{r=1}^{R} \sum_{n=1}^{N} \gamma_{i, j, r, n} H_{r, n}
$$

is the quantity of $r$-th raw materials supplied from $n$-th supplier for production of $i$-th product in $j$-th factory.

$$
\varepsilon_{i, j}=\sum_{r=1}^{R} \sum_{n=1}^{N} f_{r, n}\left(\gamma_{i, j, r, n} H_{r, n}\right)
$$

is shipping cost of $r$-th raw materials supplied from $n$-th supplier for production of $i$-th product in $j$-th factory.

$$
\varphi_{i, j}=\sum_{r=1}^{R} \sum_{n=1}^{N} t_{r, n}\left(\gamma_{i, j, r, n} H_{r, n}\right)
$$


is production cost of $r$-th raw materials supplied from $n$-th supplier for production of $i$-th product in $j$-th factory.

$$
q_{i, j}=\frac{w_{j}{ }^{2} \pi^{1}{ }_{i} K_{j}+u_{j}{ }^{2} \rho^{1}{ }_{i} L_{j}+\varepsilon_{i, j}}{G_{F j}\left(\pi^{1}{ }_{i} K_{j}, \rho^{1}{ }_{i} L_{j}\right)}
$$

unit manufacturing cost of production of $i$-th product in the factory $j$.

$$
\sigma_{i, z}=\sum_{j=1}^{J} \xi_{i, j, z} Q_{i, j}
$$

quantity of $i$ - th product producing in $j$-th factory, where $\xi_{i, j, z}$ is the portion of $i$-th product within total production of the factory $j$.

$$
\tau_{i, j, z}=\sum_{j=1}^{J} p_{i, j}\left(\xi_{i, j, z} Q_{i, j}\right)
$$

is shipping cost of $i$-th product supplied to the $z$-th Distribution Center.

$$
v_{i, z}=\frac{w_{z}^{3} v_{i} K_{z}+u_{z}^{3} \mu_{i} L_{j}+\tau_{i, z}}{G_{D C, j}\left(v_{i} K_{z}, \mu_{i} L_{z}\right)}
$$

unit purchasing cost of the product $i$-th produced by $z$-th Distribution Center.

\section{Problem Formulation.}

\section{Model 1. Optimization problem presented as a Linear Programming problem.}

As an objective function we consider the maximization of the total supply chain profit presented as a sum:

$$
\begin{array}{r}
\text { Object.Funct. }=\sum_{r=1}^{R} \sum_{n=1}^{N}\left[\left(f_{r, n}-t_{r, n}\right)\left(\sum_{i=1}^{I} \sum_{j=1}^{J} \gamma_{i, j, r, n} H_{r, n}\right)\right]+\sum_{i=1}^{I} \sum_{j=1}^{J}\left[\left(p_{i, j}-q_{i, j}\right) \sum_{z=1}^{Z} \xi_{i, j, z} Q_{i, j}\right] \\
+ \\
\sum_{i=1}^{I} \sum_{z=1}^{Z}\left[\left(c_{i, z}-v_{i, z}\right)\left(\sum_{m=1}^{M} \delta_{i, m, z} C_{i, z}\right)\right]+\sum_{i=1}^{I} \sum_{z=1}^{Z}\left[\left(e_{i, z}-v_{i, z}\right)\left(\sum_{m=1}^{M} \zeta_{i, m, z} E_{i, z}\right)\right] \rightarrow \max , \quad \text { (10) }
\end{array}
$$

where

$\sum_{r=1}^{R} \sum_{n=1}^{N}\left[\left(f_{r, n}-t_{r, n}\right)\left(\sum_{i=1}^{I} \sum_{j=1}^{J} \gamma_{i, j, r, n} H_{r, n}\right)\right]$ is the profit of the suppliers,

$\sum_{i=1}^{I} \sum_{j=1}^{J}\left[\left(p_{i, j}-q_{i, j}\right) \sum_{z=1}^{Z} \xi_{i, j, z} Q_{i, j}\right]$ is the profit of the factories,

$\sum_{i=1}^{I} \sum_{z=1}^{Z}\left[\left(c_{i, z}-v_{i, z}\right)\left(\sum_{m=1}^{M} \delta_{i, m, z} C_{i, z}\right)\right]$ is the shipping profit of the Distribution Centers providing shipping of the products,

$\sum_{i=1}^{I} \sum_{z=1}^{Z}\left[\left(e_{i, z}-v_{i, z}\right)\left(\sum_{m=1}^{M} \zeta_{i, m, z} E_{i, z}\right)\right]$ is the retail profit of the Distribution Centers providing retail of the products. 
The maximization assumes the maximization with respect to the variables $\left\{H_{r, n}\right\},\left\{Q_{i, j}\right\},\left\{C_{i, z}\right\},\left\{E_{i, z}\right\}$, where $r=1,2, \ldots, R, \quad n=1,2, \ldots, N, i=1,2, \ldots I$, $z=1,2, \ldots, Z, m=1,2, \ldots, M$.

The system of constraints is as follows.

$$
\varepsilon_{i, j}=\sum_{r=1}^{R} \sum_{n=1}^{N} f_{r, n}\left(\gamma_{i, j, r, n} H_{r, n}\right) \leq I_{i, j}^{F}
$$

The inequality (7) requires that shipping cost of raw materials supplied from raw materials suppliers for the production of $i$-th product in $j$-th factory is less than the income $I_{i, j}^{F}$ of $j$-th factory distinguished for the production of $i$-th product.

$$
\tau_{i, z}=\sum_{j=1}^{J} p_{i, j}\left(\xi_{i, j, z} Q_{i, j}\right) \leq I_{z}^{D C}
$$

The inequality (8) requires that shipping cost of $i$-th product supplied to the $z$-th Distribution Center from the $j$-th factory is less than the income $I_{z}^{D C}$ of the $z$-th Distribution Center distinguished for the purchasing of the $i$-th product.

$$
\left.\sum_{i=1}^{I} \sum_{z=1}^{Z}\left[\left(c_{i, z}-v_{i, z}\right)\left(\delta_{i, m, z} C_{i, z}\right)\right]+\sum_{i=1}^{I} \sum_{z=1}^{Z}\left[\left(e_{i, z}-v_{i, z}\right) \zeta_{i, m, z} E_{i, z}\right)\right] \leq I_{m}^{M}
$$

The inequality (9) requires that shipping cost of products supplied to the $m$-th customer is less than income $I_{m}^{M}$ of the $m$-th customer distinguished for purchasing of products produced by the factories.

Thus, we received the Linear Programming problem of maximization (10) subject to the constraints (11)-(13), which could be solved using algorithms of solution of the Linear Programming problems.

From (5)-(7) follows that

$$
\left.\sum_{r=1}^{R} \sum_{n=1}^{N}\left[\left(f_{r, n}-t_{r, n}\right) \sum_{i=1}^{I} \sum_{j=1}^{J} \gamma_{i, j, r, n} H_{r, n}\right)\right]=\sum_{r=1}^{R} \sum_{n=1}^{N} f_{r, n}\left(\sum_{i=1}^{I} \sum_{j=1}^{J} \gamma_{i, j, r, n} H_{r, n}\right)-\sum_{r=1}^{R} \sum_{n=1}^{N} \sum_{i=1}^{I} \sum_{j=1}^{J} \gamma_{i, j, r, n}\left(w_{n}^{1} \chi_{r} K_{n}+w_{n}^{2} v_{r} L_{n}\right) .
$$

\section{Model 2. Optimization problem presented as a Non-Linear Programming problem.}

Considering production functions of raw material suppliers, factories, Distribution Centers and customers the problem (10)-(13) using (14) allows the presentation as follows. Substitution of production functions into the objective function (10) gives the objective function as follows.

$$
\sum_{r=1}^{R} \sum_{n=1}^{N} f_{r, n}\left(\sum_{i=1}^{I} \sum_{j=1}^{J} \gamma_{i, j, r, n} G_{R, n}\left(\chi_{r, n} K_{n}, v_{r} L_{n}\right)-\sum_{r=1}^{R} \sum_{n=1}^{N} \sum_{i=1}^{I} \sum_{j=1}^{J} \gamma_{i, j, r, n}\left(w_{n}^{1} \chi_{r} K_{n}+w_{n}^{2} \gamma_{r} L_{n}\right)+\right.
$$




$$
\begin{gathered}
\sum_{i=1}^{I} \sum_{j=1}^{J}\left[\left(p_{i, j}-\frac{w_{j}^{2} \pi_{i}^{1} K_{j}+u_{j}^{2} \rho_{i}^{1} L_{j}+\sum_{r=1}^{R} \sum_{n=1}^{N} f_{r, n} \gamma_{i, j, r, n} G_{R, n}\left(\chi_{r} K_{n}, v_{r} L_{n}\right)}{G_{F, j}\left(\pi_{i} K_{j}, \beta_{i} L_{j}\right)}\right) \sum_{z=1}^{Z} \xi_{i, j, z} Q_{i, j}\right]+ \\
\sum_{i=1}^{I} \sum_{z=1}^{Z}\left[\left(c_{i, z}-\frac{w_{z}^{3} v_{i} K_{z}+u_{z}^{3} \mu_{i} L_{z}+\sum_{j=1}^{J} p_{i j} \xi_{i j z} G_{F, j}\left(\pi_{i} K_{j}, \beta_{i} L_{j}\right)}{G_{D C, z}\left(\nu_{i} K_{z}, \mu_{i} L_{z}\right)}\right)\left(\delta_{i, m, z} C_{i, z}\right)\right]+ \\
\sum_{i=1}^{I} \sum_{z=1}^{Z}\left[\left(e_{i, z}-\frac{w_{z}^{3} v_{i} K_{z}+u_{z}^{3} \mu_{i} L_{z}+\sum_{j=1}^{J} p_{i j} \xi_{i j z} G_{F, j}\left(\pi_{i} K_{j}, \beta_{i} L_{j}\right)}{G_{D C, z}\left(v_{i} K_{z}, \mu_{i} L_{z}\right)}\right)\left(\zeta_{i, m, z} C_{i, z}\right)\right] \rightarrow \max
\end{gathered}
$$

Further, substation of production functions into the system of constraints (11)-(13) gives the system of constraints as follows.

$$
\begin{gathered}
\varepsilon_{i, j}=\sum_{r=1}^{R} \sum_{n=1}^{N} f_{r, n}\left(\gamma_{i, j, r, n} G_{R, n}\left(\chi_{r, n} K_{n}, v_{r, n} L\right) \leq G_{F, j}\left(\pi_{i} K_{j}, \beta_{i} L_{j}\right)\right. \\
\tau_{i, z}=\sum_{j=1}^{J} p_{i, j}\left(\xi_{i, j, z} G_{F, j}\left(\pi_{i} K_{j}, \beta_{i} L_{j}\right) \leq G_{D C, z}\left(v_{i} K_{z}, \mu_{i} L_{z}\right)\right. \\
\sum_{i=1}^{I} \sum_{z=1}^{Z}\left[\left(c_{i, z}-v_{i, z}\right)\left(\delta_{i, m, z} G_{D C, z}\left(v_{i} K_{z}, \mu_{i} L_{z}\right)\right]+\right. \\
\sum_{i=1}^{I} \sum_{z=1}^{Z}\left[\left(e_{i, z}-v_{i, z}\right) \zeta_{i, m, z} G_{D C, z}\left(v_{i}^{1} K_{z}, \mu_{i}^{1} L_{z}\right)\right] \leq G_{M, m}\left(v_{i}^{2} K_{m}, \mu_{i}^{2} L_{m}\right)
\end{gathered}
$$

Assumption 1. Assume that production functions of suppliers, factories, Distribution Centers and customers are Cobb-Duglas production functions as follows:

$$
\begin{gathered}
G_{R, n}\left(K_{n}, L_{n}\right)=A_{n} K_{n}{ }^{\alpha_{n}} L_{n}{ }^{\beta_{n}}, G_{F, j}\left(K_{j}, L_{j}\right)=A_{j} K_{j}{ }^{\alpha_{j}} L_{j}{ }^{\beta_{j}}, \\
n=1,2, \ldots, n, \ldots, N, j=1,2, \ldots, j, \ldots, J(19) \\
\left.G_{Z, z}\left(K_{z}, L_{z}\right)=A_{z} K_{z}{ }^{\alpha_{z}} L_{z}{ }^{\beta_{z}}\right), G_{M, m}\left(K_{m}, L_{m}\right)=A_{m} K_{m}^{\alpha_{m}} L_{m}^{\beta_{m}}, z=1,2, \ldots, z, \ldots, Z, \\
m=1,2, \ldots, m, \ldots, M .
\end{gathered}
$$

Assumption 2. Assume that the problem of maximization is considered with respect to the following variables:

$$
\begin{gathered}
\left\{K_{n}\right\},\left\{L_{n}\right\},\left\{K_{j}\right\},\left\{L_{j}\right\},\left\{K_{z}\right\},\left\{L_{z}\right\},\left\{K_{m}\right\},\left\{L_{m}\right\} n=1,2, \ldots, n, \ldots, N, j=1,2, \ldots, j, \ldots, J, \\
z=1,2, \ldots, z, \ldots, Z, m=1,2, \ldots, m, \ldots, M .
\end{gathered}
$$

Thus, we received Non-Linear Programming problem of maximization (15) subject to the constraints (16)-(18), which could be solved using algorithm of solution of the Linear Programming problems. 


\section{Solution of the Problem (15) - (18)}

To solve the problem (15) - (18) define the Lagrangian

$$
\begin{aligned}
& E\left(\left\{K_{n}\right\},\left\{L_{n}\right\},\left\{K_{j}\right\},\left\{L_{j}\right\},\left\{K_{z}\right\},\left\{L_{z}\right\},\left\{K_{m}\right\},\left\{L_{m}\right\}, \lambda_{1}, \lambda_{2}, \lambda_{3}\right)= \\
& \sum_{r=1}^{R} \sum_{n=1}^{N} f_{r, n}\left(\sum_{i=1}^{I} \sum_{j=1}^{J} \gamma_{i, j, r, n} G_{R, n}\left(\chi_{r, n} K_{n}, v_{r} L_{n}\right)-\sum_{r=1}^{R} \sum_{n=1}^{N} \sum_{i=1}^{I} \sum_{j=1}^{J} \gamma_{i, j, r, n}\left(w_{n}^{1} \chi_{r} K_{n}+w_{n}^{2} v_{r} L_{n}\right)+\right. \\
& \sum_{i=1}^{I} \sum_{j=1}^{J}\left[\left(p_{i, j}-\frac{w_{j}^{2} \pi_{i}^{1} K_{j}+u_{j}^{2} \rho_{i}^{1} L_{j}+\sum_{r=1}^{R} \sum_{n=1}^{N} f_{r, n} \gamma_{i, j, r, n} G_{R, n}\left(\chi_{r} K_{n}, v_{r} L_{n}\right)}{G_{F, j}\left(\pi_{i} K_{j}, \beta_{i} L_{j}, \sum_{r=1}^{R} \sum_{n=1}^{N} \sum_{i=1}^{I} \sum_{j=1}^{J} \gamma_{i, j, r, n}\left(w_{n}^{1} \chi_{r} K_{n}+u_{n}^{1} v_{r} L_{n}\right) \sum_{z=1}^{Z} \xi_{i, j, z} Q_{i, j}\right]+}\right.\right. \\
& \sum_{i=1}^{I} \sum_{z=1}^{Z}\left[\left(c_{i, z}-\frac{w_{z}^{3} v_{i} K_{z}+u_{z}^{3} \mu_{i} L_{z}+\sum_{j=1}^{J} p_{i j} \xi_{i j z} G_{F, j}\left(\pi_{i} K_{j}, \beta_{i} L_{j}, \sum \sum \sum \sum_{i, j, r, n}\left(w_{n}^{1} \chi_{r} K_{n}+u_{n}^{1} L_{n}\right)\right.}{G_{D C, z}\left(v_{i} K_{z}, \mu_{i} L_{z}\right)}\right)\left(\delta_{i, m, z} C_{i, z}\right)\right] \\
& + \\
& \sum_{i=1}^{I} \sum_{z=1}^{Z}\left[\left(e_{i, z}-\frac{w_{z}^{3} v_{i} K_{z}+u_{z}^{3} \mu_{i} L_{z}+\sum_{j=1}^{J} p_{i j} \xi_{i j z} G_{F, j}\left(\pi_{i} K_{j}, \beta_{i} L_{j}\right)}{G_{D C, z}\left(v_{i} K_{z}, \mu_{i} L_{z}\right)}\right)\left(\zeta_{i, m, z} C_{i, z}\right)\right]+ \\
& \lambda_{1}\left(\sum_{r=1}^{R} \sum_{n=1}^{N} f_{r, n}\left(\gamma_{i, j, r, n} G_{R, n}\left(\chi_{r, n} K_{n}, v_{r, n} L\right)-G_{F, j}\left(\pi_{i} K_{j}, \beta_{i} L_{j}\right)\right)\right. \\
& +\lambda_{2}\left(\sum_{j=1}^{J} p_{i, j}\left(\xi_{i, j, z} G_{F,, j}\left(\pi_{i} K_{j}, \beta_{i} L_{j}\right) G_{D C, z}\left(v_{i} K_{z}, \mu_{i} L_{z}\right)\right)+\right. \\
& \lambda_{3}\left\{\sum _ { i = 1 } ^ { I } \sum _ { z = 1 } ^ { Z } \left[\left(c_{i, z}-v_{i, z}\right)\left(\delta_{i, m, z} G_{D C, z}\left(v_{i} K_{z}, \mu_{i} L_{z}\right)\right]+\right.\right. \\
& \left.\sum_{i=1}^{I} \sum_{z=1}^{Z}\left[\left(e_{i, z}-v_{i, z}\right) \zeta_{i, m, z} G_{D C, z}\left(v_{i}^{1} K_{z}, \mu_{i}^{1} L_{z}\right)\right]-G_{M, m}\left(v_{i}^{2} K_{m}, \mu_{i}^{2} L_{m}\right)\right\} .
\end{aligned}
$$

Substitute production functions (19) in Lagranjian (20). Differentiating the Lagranjian (20) and equalizing to zero partial differentials with respect to the variables

$$
\left\{K_{n}\right\},\left\{L_{n}\right\},\left\{K_{j}\right\},\left\{L_{j}\right\},\left\{K_{z}\right\},\left\{L_{z}\right\},\left\{K_{m}\right\},\left\{L_{m}\right\} n=1,2, \ldots, n, \ldots, N, j=1,2, \ldots, j, \ldots, J,
$$
$z=1,2, \ldots, z, \ldots, Z, m=1,2, \ldots, m, \ldots, M$ and $\lambda_{1}, \lambda_{2}, \lambda_{3}$ allows to receive the system of nonlinear equations. To solve this system we could use the Newton method of the solution of nonlinear system of equations [1, pp. 450-469]. 


\section{Model 3. Optimization problem presented as a Non-Linear Problem of Stochastic Programming.}

Assumption 3. Assume that demand of the product $i$ is contingent, $i=1,2, . ., I$.

Thus, denote $v_{i m z \theta}$ - unit shipping cost of the product $i$ from DC $z$ for the customer $m$ (in the state $\theta, \quad i=1,2, \ldots, I, m=1,2, \ldots, M, \theta=1,2, \ldots, s$,

$\vartheta_{\text {imz } \theta}$ - unit purchasing cost of the product $i$ by the customer $m$ from DC $z$ (in the state $\theta, \quad i=1,2, \ldots, I, m=1,2, \ldots, M, \theta=1,2, \ldots, s$,

$E_{i m z \theta}$-shipping quantity of the product $i$ from the DC $z$ to the customer $m$ with probability

$$
h_{\theta}, i=1,2, \ldots, I, m=1,2, \ldots, M, z=1,2, \ldots, Z, \theta=1,2, \ldots, s, \sum_{\theta=1}^{s} h_{\theta}=1 .
$$

Hence, the expected profit of the DC is

$$
W\left(\left\{v_{i m z \theta}\right\},\left\{\vartheta_{i m z \theta}\right\},\left\{E_{i m z \theta}\right\}\right)=\sum_{i=1}^{I} \sum_{m=1}^{M} \sum_{z=1}^{Z} \sum_{\theta=1}^{s} E_{i m z \theta}\left(v_{i m z \theta}-\vartheta_{i m z \theta}\right) h_{\theta}
$$

Consequently, the objective function Object.funct.+ $W\left(\left\{v_{\text {imz } \theta}\right\},\left\{\vartheta_{\text {imz } \theta}\right\},\left\{E_{\text {imz } \theta}\right\}\right)$, which is a sum of objective functions (10) and (21) together with constraints (11) - (14) gives the Linear Stochastic Programming problem. This problem is solved by complete implementation of the Benders Algorithm given in [6].

\section{Summary}

Present research has clarified that problems emerging between the seller and the buyer have a nature of uncertainty and allow to be modeled with respect to global optimization of the Supply Chain. In contrary to the Supply Chains under complete information, the present paper studied the Supply Chain management problems with assumption that some variables of the system are uncertain. Taking into account that uncertainty of the Supply Chain allows increasing its applicability we developed the model as well the algorithm of global optimization.

In addition, the models of certainty of the SC are considered and the approach for the optimization algorithm is presented.

\section{Bibliography}

1. DEMIDOVICH B.P., MARON I.A. Basics of the Numerical Mathematics, Moscow, Publ. "Nauka", 1966, p.664, (in Russian).

2. KHACHATRYAN H., Supply Chain: Uncertainty and Coordination//Proceedings of Engineering Academy of Armenia. 2010. vol.7, No1, pp.35-39

3. MUNSON C., ROSENBLAT M. Theories and realities of quantity discounts: An exploratory study. Production and Operation Management, 1998, 7(4), pp. 352-369.

4. SINHA S.,SARMAH S.P. An application of fuzzy set theory for supply chain coordination. International Journal of Management Science and Engineering Management, vol. 3 (2008) No. 1, pp.19-32. 
5. YANG C., WEE M. An arbores cent inventory model in a supply chain system. Production Planning and Control, 2001, 12(8): p.728-735

6. $\quad 4$ http://www.amsterdamoptimization.com/models/twostage/stochbenders.g ms

\section{Kopsavilkums}

Šis raksts ir veltīts piegādes ķēdes (SC) pārvaldības problēmu izpētei. Šīs problēmas ir radījušas būtiskus jautājumus par nenoteiktību un vajadzībām optimizēt pārvaldības procesu dažādās saimniecības nozarēs. Tādējādi SC iesaistīto organizāciju uzmanības centrā ir pašu peḷnas maksimāla palielināšana. Šì prasība nodrošina vajadzību sasniegt SC organizācijas mērksi kā ieguldīto un iegūto resursu pārvaldīšanu.

Pašreizējās SC vadības problēmas ar pilnīgu informāciju ir intensīvi pētītas dažādos pētījumos. Šajos pētījumos par vienu no efektīviem SC koordinācijas mehānismiem tiek uzskatīta vairumatlaide. Kā to $\mathrm{SC}$ vadības problēmu izpētes attīstība, kas saistītas ar nenoteiktību, tiek apsvērta neprecīzā daudzuma teorijas izmantošana piegādes k̦ēdes koordinācijai, un ir izveidots sadarbības mehānisms, izmantojot vairumatlaižu politiku atbilstoši asimetriskajai informācijas videi.

SC koordinācija ļauj atšksirt turpmāk minētās trīs kategorijas. Kategorijā, kas attiecas uz pircēja perspektīvo modeli, tiek ṇemta vērā pircēja prasību optimizācijas problēma, pien,emot, ka pārdevējiem ir pilnīga informācija par pircēja izmaksu struktūru.

Nākamā kategorija attiecas uz pārdevēja perspektīvo modeli, kad cenu noteikšanas sistēma ir „izdevīga pārdevējam, kamēr pircējam(-iem) piedāvātās atlaides ir mazākas par pārdevēja izmaksu ekonomiju".

Starp SC modeliem ievērojams pētījumu apjoms ir veltīts apvienotajai pircēja pārdevēja modeḷu kategorijai. Šajā model̦u kategorijā tiek n,emtas vērā vairumatlaižu stratēgijas, kas maksimāli palielina sistēmas peḷnu.

Visos šajos gadījumos nav zināma precīza parametru vērtība un lēmumu pieñēmējs saskaras ar nenoteiktību. Ja nav pilnīgas informācijas, tad lēmumu pieṇēmējs var nezināt, kādas sekas ir konkrētajai viṇa izdarītajai izvēlei. Tāpēc ir labāk, ja pieejama informācija, kas mazina nenoteiktību, un līdz ar to tiek pien,emti labāki lēmumi, kas nodrošina sistēmas pel̦nas palielinājumu.

N̦emot vērā šìs iezīmes, šajā rakstā tiek pētīta saistība starp nenoteiktību un informācijas iegūšanu. Tas ḷauj mazināt iztrūkumus SC literatūrā, ierosinot kopējās izmaksas, kas sastāv no divu veidu izmaksām: nenoteiktām izmaksām un noteiktām izmaksām. Nepieciešami vairāki pieṇēmumi, lai nodrošinātu saprotamus analīzes rezultātus. Pirmkārt, piegādātājs un rūpnīcas kā SC objekti ir pilnīgi nodrošināti ar diviem ražošanas faktoriem - darbaspēku un kapitālu. Šie divi faktori tiek izmantoti šādām ražošanas darbībām: pirmkārt, abi faktori tiek izmantoti, lai iegūtu viendabīgu galaprodukciju (izejvielas no klientiem).

Piegādes k̦ēdes maksimālas palielināšanas ar nenoteiktību pieeja, kuras mērḳis ir koordinēšana, tiek parādīta kā Lineārās programmēšanas problēma nenoteiktībā.

Tiek apskatīta Integrēta piegādes ksēde ar vairākiem ražotājiem, vairākiem piegādātājiem, vairākiem izplatītājiem un vairākiem klientiem. Turklāt tiek pētīta pieeja optimizācijai, pamatojoties uz apsvērumiem par modeli ar nelineāru objektīvo funkciju un nelineāru ierobežojumu sistēmu. Šīs problēmas atrisināšanai piedāvāts algoritms N̦ūtona pieskaru metodei (nelineāras) vienādojumu sistēmas atrisināšanai. 